\title{
RESEARCH AND DIDACTIC GAMES
}

\section{Martin HIBKÝ}

Abstract: Artikle brings out the possibility of using didactic game for research in the field of education. It focuses on the performance of the methodology and interpretation of results in the teacher's personality from the perspective of students. Report has explorative character and includes results processed by statistical methods.

Key words: didactic game, teachers personality, quantitative research

\section{VÝSKUM A DIDAKTICKÉ HRY}

Resumé: Príspevok predstavuje možnost' použitia didaktickej hry na výskum v oblasti didaktiky. Sústred'uje na predstavenie metodiky a interpretáciu zistených výsledkov voblasti osobnosti učitel’a z pohl’adu žiakov. Príspevok má výskumný charakter a obsahuje výsledky spracované štatistickými metódami.

Klúčová slová: didaktická hra, osobnost' učitel’a, kvantitatívny výskum

\section{1 Úvod}

Metódy používané na výskum voblasti didaktiky sa do značnej miery rôznia, pretože každá oblast' výskumu či už v didaktike, ale aj v iných vedných odboroch si vyžaduje špecifický prístup a vhodne zvolené metódy. Ciel'om tohto príspevku je na praktickej ukážke interpretovat' možnost' použitia didaktickej hry na reálny výskum vo vybranej oblasti. V našom prípade sme sa sústredili na výskum v oblasti osobnosti učitel'a, pričom naším zámerom nebolo skúmat' psychologické príčiny preferencie daných vlastností žiakmi, ale pomocou štatistických analýz popísat' vybrané závislosti. Príspevok taktiež teoreticky neanalyzuje osobnost' učitel'a, ale sústred'uje sa na predstavenie metodiky a podrobnú analýzu zistených výsledkov. Porovnanie niektorých teoretických poznatkov s nami zistenými výsledkami je súčast'ou diskusie.

Výsledky boli získané počas školského roku 2012/2013 od 25 učebných a študijných skupín $\mathrm{z}$ vybranej strednej školy $\mathrm{v}$ Novom Meste nad Váhom.

\section{Ciel'}

Ciel'om výskumu bolo zistit' pomocou didaktickej hry žiakmi preferované vlastnosti učitel'a z vybranej skupiny 20 vlastností a štatisticky verifikovat’ vybrané závislosti.

\section{Hypotézy}

H1: Predpokladáme, že údaje zistené formou didaktickej hry nám prinesú štatisticky verifikovatel'né údaje pre naplnenie ciel’a.

H2: Predpokladáme, že preferencie žiakov nie sú rozdelené rovnomerne na všetky dané vlastnosti.

H3: Predpokladáme, že existuje signifikantný rozdiel medzi preferenciami učebných a maturitných skupín.

\section{Použité výskumné metódy}

Ako výskumná metóda bola zvolená didaktická hra pomenovaná autorom ako 5 z 20. Námet hry pochádza $z$ príručky pre animátorov (Babják, 2001), ale je bežne dostupná aj v iných publikáciách (Zelinová, 2011).

Celá hra bola spracovaná v programe - Acitiv Inspare určenom pre interaktívnu tabul'u, kde mala štruktúru zobrazenú na obrázku 1. Učitel' rozdelil žiakov do skupín od 7-12 l'udí a vyzval ich, aby si v rámci skupiny zvolili po dôkladnej diskusii $5 \mathrm{z}$ daných 20 vlastností, ktoré by mal mat' podl'a nich dobrý učitel'. Po zvolení si ich jednotlivé skupiny presúvali do pripravených stĺpcov obrázok 2. Po výbere nasledovala diskusia o dôvodoch ich vol'by. 
Q

\begin{tabular}{|c|c|}
\hline & Srdečný \\
\hline Trpezlivý & Kritický voči žiakom \\
\hline Ochotný diskutovat' & Pokrokovỹ \\
\hline Všetko nám dovolí & Moderne sa oblieka \\
\hline Vie počúvat' & Vážiaci si žiakov \\
\hline Nábožný & Vie sa ovládat' \\
\hline Zásadovỳ & Priatelský \\
\hline Vie pochopit žiaka & Odborník \\
\hline Prísny & Vtipný \\
\hline Sebakritický & Má jasné pravidlá \\
\hline
\end{tabular}

Obrázok 1 Zadanie hry

\begin{tabular}{|c|c|c|c|}
\hline \multirow{3}{*}{\begin{tabular}{|c|} 
Srdečný \\
Kritický voči žiakom
\end{tabular}} & \multicolumn{2}{|c|}{ Whodnotenie: } & \multirow[b]{2}{*}{ Tolerantný } \\
\hline & 1. skupina & 2 skupina & \\
\hline & Vtipný & Tolerantný & Trpezlivý \\
\hline Pokrokový & Priatel'ský & Trpezlivý & Ochotný diskutovat \\
\hline Moderne sa oblieka & Zásadový & Srdečný & Všetko nám dovoli \\
\hline Vážiaci si žiakov & Ochotný diskutovat & Vtipný & Vie počúvat \\
\hline & Trpezlivý & Sebakritický & \\
\hline Vie sa ovládat & & & Nábožný \\
\hline Priatel'ský & & & Zásadový \\
\hline Odbornik & & & Vie pochopit žiaka \\
\hline Vtipný & & & Prisny \\
\hline Má jasné pravidlá & & & Sebakritický \\
\hline
\end{tabular}

Obrázok 2 Ukážka vyplnenej hry

\section{Výskumná vzorka}

Výskumnú vzorku tvorilo celkovo 10 skupín vytvorených z učebných odborov a 15 skupín vytvorených z maturitných odborov. Rozsah skupín bol variabilný od 7 - 12 žiakov.

\section{6 Štatistická analýza získaných výsledkov}

Znenie hypotézy H1: Predpokladáme, že údaje zistené formou didaktickej hry nám prinesú štatisticky relevantné údaje pre naplnenie ciel'a.

Overenie hypotézy H1: Ako vidiet' z tabul'ky 1 , táto metóda nám priniesla kvantifikovatel'né údaje. $\mathrm{Na}$ základe štruktúry zhromaždených údajov, ktoré nám umožnili d’alšiu analýzu konštatujeme, že hypotéza H1 sa potvrdila.
Tabul'ka 1 Početnost' a štruktúra zhromaždených údajov

\begin{tabular}{|c|c|c|c|}
\hline \multirow{2}{*}{ por... } & \multirow{2}{*}{ vlastnost' } & \multicolumn{2}{|c|}{ Rozloženie početnosti } \\
\hline & & učebné odbory & maturitné odbory \\
\hline 1. & tolerantný & 5 & 7 \\
\hline 2. & trpezlivy & 5 & 6 \\
\hline 3. & ochotný diskutovat' & 1 & 5 \\
\hline 4. & všetko nám dovolí & 6 & 4 \\
\hline 5. & vie počúvat' & 0 & 5 \\
\hline 6. & nábožný & 1 & 0 \\
\hline 7. & zásadový & 0 & 1 \\
\hline 8. & vie pochopit' žiaka & 4 & 8 \\
\hline 9. & prísny & 0 & 1 \\
\hline 10. & sebakritický & 0 & 2 \\
\hline 11. & srdečný & 1 & 4 \\
\hline 12. & kritický voči žiakom & 0 & 0 \\
\hline 13. & pokrokoví & 2 & 0 \\
\hline 14. & moderne sa oblieka & 1 & 0 \\
\hline 15. & váži si žiakov & 6 & 5 \\
\hline 16. & vie sa ovládat & 2 & 2 \\
\hline 17. & priatel'ský & 5 & 9 \\
\hline 18. & odbornik & 2 & 1 \\
\hline 19. & vtipný & 8 & 11 \\
\hline 20. & má jasné pravidlá & 2 & 4 \\
\hline & Celková početnost' & 51 & 75 \\
\hline
\end{tabular}

Znenie hypotézy H2: Predpokladáme, že preferencie žiakov nie sú rozdelené rovnomerne na všetky dané vlastnosti.

Overenie hypotézy H2: $\mathrm{Na}$ overenie $\mathrm{H}_{2}$ sme použili $\chi^{2}$ - test dobrej zhody, ktorý je najpoužívanejší z testov dobrej zhody. Vol'ba daného testu bola zámerná, ked’že $\mathrm{v}$ našom prípade sme nechceli testovat' iba niektoré parametre základných súborov (rozptyl, strednú hodnotu, atd'.), ale zhodu týchto súborov $\mathrm{v}$ širšom zmysle, a to zhodu rozdelení. Oproti hypotéze $\mathrm{H}_{2}$ si teda postavíme testovanú hypotézu $\mathrm{H}_{0}$, ktorá hovorí o zhode medzi empirickým a teoretickým rozdelením (Easton, 1997). Ako testovacie kritérium použijeme štatistiku (Markechová, 2011):

$$
\chi^{2}=\sum_{j=1}^{k} \frac{\left(f_{e, j}-f_{o, j}\right)^{2}}{f_{o, j}} .
$$

Rozloženie teoretických a emipirických početností je zhrnuté $\mathrm{v}$ tabul'ke 2. Ako $\mathrm{v}$ danej tabul'ke vidno teoretická početnost' $\mathrm{f}_{\mathrm{o}, \mathrm{j}}=6,3$. Tým sme splnili podmienku pre použitie $\chi^{2}-$ testu a to $\mathrm{f}_{\mathrm{o}, \mathrm{j}} \geq 5$ pre $\mathrm{j}=1,2, \ldots . . \mathrm{k}$. 
Tabul'ka 2 Porovnanie empirických a teoretických početností pre jednotlivé vlastnosti

\begin{tabular}{|c|c|c|c|}
\hline por. č. & vlastnost & $\begin{array}{l}\text { Empirické } \\
\text { početnosti }\end{array}$ & $\begin{array}{l}\text { Teoretické } \\
\text { početnosti }\end{array}$ \\
\hline 1. & tolerantný & 12 & 6,3 \\
\hline 2. & trpezlivý & 11 & 6,3 \\
\hline 3. & ochotný diskutovat' & 6 & 6,3 \\
\hline 4. & všetko nám dovoli & 10 & 6,3 \\
\hline 5. & vie počúvat & 5 & 6,3 \\
\hline 6. & nábožný & 1 & 6,3 \\
\hline 7. & zásadový & 1 & 6,3 \\
\hline 8. & vie pochopit žiaka & 12 & 6,3 \\
\hline 9. & prisny & 1 & 6,3 \\
\hline 10. & sebakritický & 2 & 6,3 \\
\hline 11. & srdečný & 5 & 6,3 \\
\hline 12. & kritický voči žiakom & 0 & 6,3 \\
\hline 13. & pokrokovy & 2 & 6,3 \\
\hline 14. & moderne sa oblieka & 1 & 6,3 \\
\hline 15. & váži si žiakov & 11 & 6,3 \\
\hline 16. & vie sa ovládat & 4 & 6,3 \\
\hline 17. & priatel'ský & 14 & 6,3 \\
\hline 18. & odbornik & 3 & 6,3 \\
\hline 19. & vtipný & 19 & 6,3 \\
\hline 20. & má jasné pravidlá & 6 & 6,3 \\
\hline \multicolumn{2}{|c|}{ Celková početnost } & 126 & 126 \\
\hline
\end{tabular}

Po dosadení príslušných početností je hodnota testovacieho kritéria $\chi^{2}=87,651$. V tabul'ke kritických hodnôt $\chi^{2}-$ rozdelenia si nájdeme kritickú hodnotu pre daný počet stupňov vol'nosti $\mathrm{k}-1=20-1=19 \cdot \chi_{\text {krit }}^{2}=30,144$.

\section{Interpretácia výsledkov:}

Ked'že hodnota testovacieho kritéria $\chi^{2}$ $(87,651)>\chi_{\text {kritická }}^{2}(30,144)$, testovanú hypotézu $\mathrm{H}_{0}$ na hladine významnosti $\alpha=0,05$ o zhode $\mathrm{v}$ rozdelení zamietame a konštatujeme, že rozdiel medzi empirickými a očakávaný početnost’ami je štatisticky významný. To znamená, že žiaci nepreferovali jednotlivé vlastnosti rovnako. Hypotéza $\mathrm{H} 2$ sa potvrdila!

Pri bližšej analýze sa dá zistit', že 70,63\% početností je kumulovaných okolo 7 vlastností: vtipný-15,08\%, priatel'ský-11,11\%, vie pochopit' žiaka-9,52\%, tolerantný-9,52\%, váži si žiakov$8,73 \%$, trpezlivý- $8,73 \%$, všetko nám dovolí$7,94 \%$. Toto rozdelenie je zretel'né aj v grafe 1 .

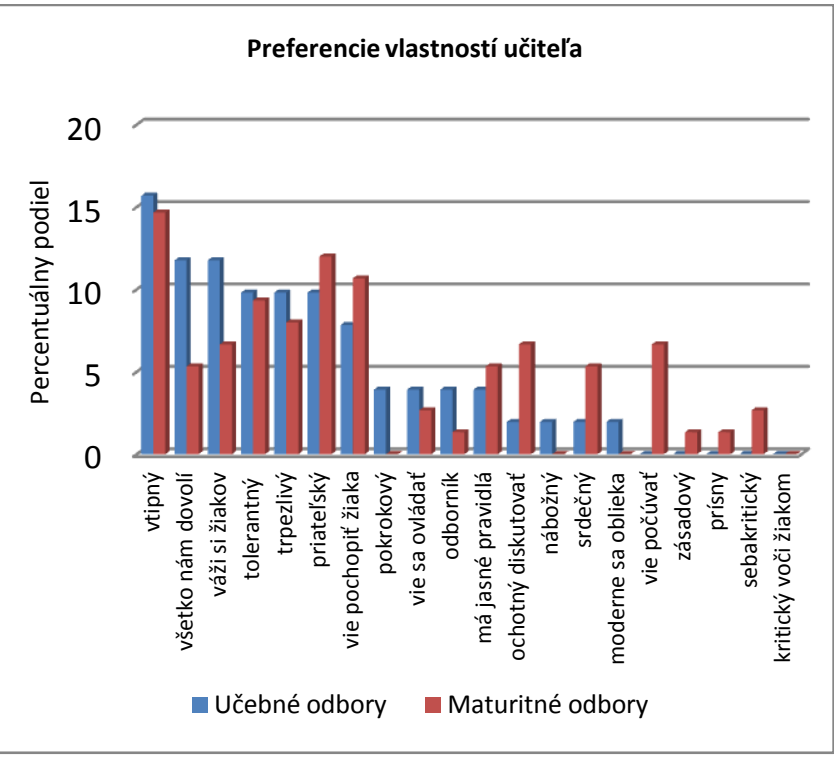

Graf 1 Početnost' jednotlivých preferencií

Znenie hypotézy H3: Predpokladáme, že existuje signifikantný rozdiel medzi preferenciami učebných a maturitných skupín.

Overenie hypotézy H3: $\mathrm{Na}$ overenie $\mathrm{H}_{3}$ sme použili Kolmogorovov-Smirnovov dvojvýberový test o zhode rozdelení dvoch súborov. Oproti hypotéze $\mathrm{H}_{3}$ si teda postavíme testovanú hypotézu $\mathrm{H}_{0}$, ktorá hovorí, že oba súbory pochádzajú z toho istého základného súboru. Ked'že výberové súbory majú dostatočne vel'ké rozsahy $\mathrm{n}_{1}, \mathrm{n}_{2}\left(\mathrm{n}_{1}>40, \mathrm{n}_{2}>40\right)$, ako testovacie kritérium použijeme štatistiku (Markechová, 2011):

$$
D_{2}^{\prime}=\operatorname{maximum}\left|R_{1, j}-R_{2, j}\right|
$$

Kde: $R_{1, j}$ - označuje relatívnu kumulatívnu početnost' j-tej triedy prvého výberu, $R_{2, j}$ - označuje relatívnu kumulatívnu početnost' j-tej triedy druhého výberu.

Testovanú hypotézu $\mathrm{H}_{0}$ o zhode rozdelení zamietneme ak pre hodnotu testovacieho kritéria platí $\mathrm{D}_{2}^{\prime} \geq \mathrm{D}_{2 ; \alpha}^{\prime}$. Kritické hodnoty $\mathrm{D}_{2 ; \alpha}^{\prime}$ vypočítame pre $\alpha=0,05$ podl'a nasledujúceho vzt’ahu (Markechová, 2011):

$$
D_{2 ; 0,05}^{\prime}=1,36 \cdot \sqrt{\frac{n_{1}+n_{2}}{n_{1} \cdot n_{2}}}
$$

Po dosadení príslušných početností je najväčší $\mathrm{z}$ rozdielov 0,122353 . Teda hodnota testovacieho kritéria $\mathrm{D}_{2}^{\prime}=0,122353$ čo môžeme vidiet' $\mathrm{V}$ tabul'ka 3. 
Tabul'ka 3 Početnosti, relatívne početnosti, kumulatívne relatívne početnosti pre oba výbery

\begin{tabular}{|c|c|c|c|c|c|c|c|}
\hline vlastnost' & 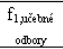 & 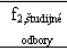 & $\mathrm{F}_{1, j} / \mathrm{n}_{1}$ & $\mathrm{~F}_{2 j} / \mathrm{n}_{2}$ & $R_{1, j}$ & $\mathrm{R}_{2 \mathrm{j}}$ & $/ \mathrm{R}_{1, \mathrm{j}}-\mathrm{R}_{2 \mathrm{j}} \mathrm{j}^{\prime}$ \\
\hline tolerantný & 5 & 7 & 0,098039 & 0,093333 & 0,098039 & 0,093333 & 0,00471 \\
\hline trpezlivý & 5 & 6 & 0,098039 & 0,08 & 0,196078 & 0,173333 & 0,02275 \\
\hline ochotný diskutovat' & 1 & 5 & 0,019608 & 0,066667 & 0,215686 & 0,24 & 0,024314 \\
\hline všetko nám dovolí & 6 & 4 & 0,117647 & 0,053333 & 0,333333 & 0,293333 & 0,04 \\
\hline vie počúvat & 0 & 5 & 0 & 0,066667 & 0,333333 & 0,36 & 0,026667 \\
\hline nábožný & 1 & 0 & 0,019608 & 0 & 0,352941 & 0,36 & 0,007059 \\
\hline zásadový & 0 & 1 & 0 & 0,013333 & 0,352941 & 0,373333 & 0,020392 \\
\hline vie pochopit' žiaka & 4 & 8 & 0,078431 & 0,106667 & 0,431373 & 0,48 & 0,048627 \\
\hline prisny & 0 & 1 & 0 & 0,013333 & 0,431373 & 0,493333 & 0,061961 \\
\hline sebakrritický & 0 & 2 & 0 & 0,026667 & 0,431373 & 0,493333 & 0,061961 \\
\hline srdečný & 1 & 4 & 0,019608 & 0,053333 & 0,45098 & 0,56 & 0,10902 \\
\hline kritický voči žiakom & 0 & 0 & 0 & 0 & 0,45098 & 0,573333 & 0,122353 \\
\hline pokrokový & 2 & 0 & 0,039216 & 0 & 0,490196 & 0,573333 & 0,083137 \\
\hline moderne sa oblieka & 1 & 0 & 0,019608 & 0 & 0,509804 & 0,573333 & 0,063529 \\
\hline vážiaci si žiakov & 6 & 5 & 0,117647 & 0,066667 & 0,627451 & 0,64 & 0,012549 \\
\hline vie sa ovládat' & 2 & 2 & 0,039216 & 0,026667 & 0,666667 & 0,666667 & 0 \\
\hline priatel'ský & 5 & 9 & 0,098039 & 0,12 & 0,764706 & 0,786667 & 0,021961 \\
\hline odbornik & 2 & 1 & 0,039216 & 0,013333 & 0,803922 & 0,8 & $-0,00392$ \\
\hline vtipný & 8 & 11 & 0,156863 & 0,146667 & 0,960784 & 0,946667 & 0,014118 \\
\hline má jasné pravidlá & 2 & 4 & 0,039216 & 0,053333 & 1 & 1 & 0 \\
\hline$\sum$ & 51 & 75 & - & - & - & - & - \\
\hline
\end{tabular}

\section{Interpretácia výsledkov:}

Ked'že hodnota testovacieho kritéria je menšia ako kritická $\mathrm{D}_{2}^{\prime}(0,1224)<\mathrm{D}_{2 ; \alpha}^{\prime}(0,2468)$; nulovú hypotézu $\mathrm{H}_{0}$ o zhode rozdelení nemôžeme na hladine významnosti $\alpha=0,05$ zamietnut'. To znamená, že medzi preferenciami učebných a študijných odborov vo vlastnostiach učitel'ov nie je štatisticky významný rozdiel. Hypotéza H3 sa nepotvrdila!

\section{Záver a diskusia:}

Pomocou uvedených analýz sa nám podarilo verifikovat' stanovené hypotézy, čím sme naplnili stanovený ciel' a preukázali sme vhodnost' didaktickej hry pre výskum v didaktike. Nami zistené výsledky zároveň korešpondujú s teoretickými úvahami (Fontana, 2010), kde autor popisuje 16 pravidiel, ktoré by mali byt' integrované do osobnosti učitel'a. Medzi inými odporúča aj tieto pravidlá:
a) bud'te zábavní
b) ukážte, že máte deti radi
c) bud'te spravodlivý
d) vystríhajte sa pokorovaniu detí
e) nepodliehajte hnevu
f) používajte pozitívne upozornenia

Podobne uvádza požiadavky na osobné a charakterové vlastnosti učitel'a aj Turek (2008) a to v nasledujúcom poradí: čestnost', svedomitost', usilovnost', spravodlivost', trpezlivost', dôslednost', zodpovednost', sebaovládanie, dobrý vzt’ah k l'ud'om, tvorivost', dobré vyjadrovacie schopnosti, logickost' a systematickost' myslenia, zmysel pre humor a pod. Ako vidiet' aj $\mathrm{v}$ tomto prípade odporúčania čiastočne korešpondujú s nami zistenými preferenciami žiakov analyzovanými v druhej hypotéze. Týmto porovnaním s našimi výsledkami meraní môžeme potvrdit' opodstatnenost' skôr zistených teoretických odporúčaní, ktoré korešpondujú s postojmi žiakov zistených na našej vzorke v súčasnosti. Navyše verifikácia hypotézy $\mathrm{H} 3$ naznačuje, že preferencie žiakov nie sú závislé od druhu a úrovne školy. Na zovšeobecnenie tohto tvrdenia je však potrebná širšia analýza tejto otázky a porovnanie aj d'alších stupňov škôl. Nepotvrdenie H3 môže taktiež znamenat', že klesá rozdiel medzi preferenciami učebných a študijných odborov $\mathrm{v}$ dôsledku celkového znižovanie úrovne stredných škôl s maturitou na Slovensku.

$\mathrm{Na}$ základe uvedeného však jednoznačne konštatujeme, že vhodne zostavená didaktická hra je relevantným a plne funkčným výskumným nástrojom.

\section{Literatúra}

[1] BABJAK, A. 2002. Kuchárka pre animátora. Aktivizujúce metódy pri práci s mládežou : ZKSM, 2002. 153 s. ISBN 80968561-0-3

[2] EASTON, V. J. - McCOLL. 1997. Statistics Glossary [online]. Steps, 1997 [cit. 2013-05-16] Dostupné z:

http://www.stats.gla.ac.uk/steps/glossary/categori cal_data.html\#chigof

[3] FONTANA, D. 2010. Psychologie ve školní praxi : Portál, 2010. 383 s. ISBN 978-80-7367725-1

[4] MARKECHOVÁ, D. - TIRPÁKOVÁ, A. STEHLÍKOVÁ, B. 2011. Základy štatistiky pre pedagógov. Nitra : FPV UKF, 2011. 405 s. ISBN 978-80-8094-899-3

[5] TUREK, I. 2008. Didaktika. Bratislava : Iura Edition, 2008. 596 s. ISBN 978-80-8087 198-9

[6] ZELINOVÁ, M. 2011. Hry pro rozvoj emocí a komunikace: koncepce a model tvorivé humanistické výchovy. Praha : Portál, 2011. 144 s. ISBN 978-80-262-0036-9

Ing. Martin Hibký, PhD.

SOŠ Piešt’anská 2262/80,

91501 Nové Mesto nad Váhom, SR

Tel: +421 908125524

E-mail: martinhibky@gmail.com 